\title{
Shepherding Public Discourse Practices: Homiletic Form Aligned to the Logic Operative in Racial Rhetoric and Public Theological Discourse for Secular Liberal Democracies
}

\author{
Maury Jackson \\ La Sierra University HMS Richards Divinity School, Riverside, USA \\ Horace Crogman \\ The Institute of Effective Thinking, Riverside, USA \\ College of the Desert, Palm Spring, USA
}

\begin{abstract}
Given that preaching is the primary mode of public theological discourse for most Christian ministers, an intellectual virtue of verbal restraint is required when practicing public theology and it is wise to address the ways that homilies can shepherd public discourse practices. A theology of rhetoric includes the homilist's moral purpose. Homilies either enhance public discourse or pervert it. This essay sketches a pattern of sermon movement that respects the logic operative in public theology, given the social context of America. Homilies can help cultivate the pastoral care of public rhetoric by modeling discourse that nurtures the politics of accountability. While many call for a public ethos where divergent moral voices engage each other in highly contested arenas, a precondition to practicing effective public theology requires that one exercises discourse in a way that respects the social limits on the free exercise of religion. It is important that a public theology of rhetoric clarifies the original social agreement for acceptable religious discourse in the public arena. Homiletics, as a dimension of practical theology, can teach preachers methods of pastoral care for public discourse. The social agreement in liberal democracies to contain the combative nature of religious discourse assumes a logic that is circumscribed by commitments to (1) religious pluralism, (2) theological agnosticism, and (3) epistemological pragmatism. Here we propose that a sermon’s form, which implicitly touches upon these commitments, can tap into the basic modes of persuasion in secular liberal societies. This respects the moral purposes previously agreed upon and expected of partisans during highly contestable times. This calls for incarnational humility on the part of the Christian public theologian and it guides her/his practice.
\end{abstract}

Keywords: homiletics, liberal democracy, secularization, Bonhoeffer, radical theology, rhetoric

\section{Introduction: Public Theology, Pastoral Care, and the Discourse Environment}

We explored the reactions of coffee shop customers to their perceived receptivity for conversation, with the apparently religious and the apparently secular person, by setting up the following ad hoc experiment. A

Maury Jackson, D.Min., Associate Professor, HMS Richards Divinity School, La Sierra University.

Horace Crogman, Ph.D., Research Specialist, The Institute of Effective Thinking, and Assistant Professor, College of the Desert.

Correspondence concerning this article should be addressed to Maury Jackson. 
pastor and philosophy professor were placed at a vantage point, in a coffee shop, holding a book with a noticeable religious title. When patrons inquired about the reading, the research assistants were to show enthusiasm about the book's impact on their thinking. Results to the experiment first revealed a general curiosity and interest in the book's subject. Secondly, when asked about the booklover's profession, two main reactions ensued: (1) if the experimenter revealed the profession of pastor, customers congratulated him/her and moved on; (2) if he/revealed the profession of philosophy professor, customers engaged the experimenter further and maintained a longer conversation, not about philosophy but about theology. These findings revealed important points: there was a general interest in "God talk", a diverse level of customer sophistication with regard to religious matters, and customers also honored both types of professions and the wisdom each experimenter had as a specialist in religious studies. However, the receptivity toward the philosopher as a conversation partner leaves room for speculation as to the customers' opinions about clergy and philosophers with regard to discourse partners on religious matters.

While this ad hoc informal question and response is not held as a model for research design, one can nevertheless, developed a hunch about the intuitions of many people today. People, in secular liberal democracies, implicitly feel that when religious talk takes place in the public sphere, philosophers are better moderators than pastors. It is as if the philosopher has become the secular priest who is able to lead sensitive discussion topics. This bias toward the "neutral rules" of secular philosophy warrants a conceptual investigation into the nature and role of public religious discourse during highly contested times.

No doubt, there are many reasons for the loss of public confidence in the clergy's ability to moderate religious discourse. The voices of religious speakers, who were influential in higher education in past times, also served as instruments of oppression and division among the races. Wilder (2014) argues that, "colleges stopped being instruments for Christianizing Native people and became a means of effacing the religious and national divisions between European colonists,” and that university faculties collected and processed information about human differences from which they forged theories of biological supremacy of whites over African Blacks. Consequently, to practice public theology society strike need recognized the need to culturally enforce the built in mechanisms to curb, impede, and limit public theological convictions in ways that respect the social limits on the free exercise of religion. ${ }^{1}$

Homiletic thought aids preachers as it clarifies the social agreement for acceptable religious discourse in the public arena. We argue that religious speakers should design their sermons, homilies, and addresses such that they adhere to this agreement. Yes, we recognize that this is difficult given the fact that the speaker's role in the public discourse space has become recast to have low impact. Nevertheless, religious speakers are formed by and are forming agents in discursive communities. While the sermon's influence on the discourse environment might seem small, it nonetheless, contributes to building up or tearing down public discourse.

Sermons are the primary mode of public theological discourse for most Christian ministers. And Christian houses of worship are public spaces. Taken together these two propositions suggest that sermons are preached in public forums and (whether good or bad) they model public theological discourse. It is the case that the influence these houses of worship have is dwindling as the public discourse becomes more secularized and divided. Thus, public theology in this sense is to take university or church contexts as public and not as private

\footnotetext{
1 These limits, encoded in the society's laws, empower the state to use coercive force, when needed, in order to curb religious freedom for the sake of the common good. See John Courtney Murray, Religious Liberty: Catholic Struggles with Pluralism. (Louisville, KY: Westminster John Knox Press, 1993), pp. 66-67.
} 
forums. This claim differs from that of the secular philosopher John Rawls (1993, p. 220) who argues that church meetings are private affairs. This is patently ridiculous. The claim that a worship gathering is a public forum appears to need no justification. After all, sermons are delivered in worship gatherings that welcome the public. And sermons are presented to hearers who are challenged to go back into the larger public arena and cultivate a better community.

Some Christians feel threatened in today's American culture where forces within the secular society seek to confine faith to the private spaces of church halls. For these persons, the work of Christianity in human community has acted best when it has acted to transform society from the oppressiveness of tyrants. At times the Christian voice has been the first voice heard speaking against oppression. This was the case with respect to Telemachus' impact in helping to bring an end to the gladiatorial games of the Roman coliseums, the abolitionists' struggle against slavery, Dietrich Bonheoffer's voice against Nazi Germany, or black Christianity's leadership in fighting for racial equality during the Civil Rights Era. Furthermore, a case can be made that biblical passages, which on a surface reading appear to show Christian acquiescence to the depraved cultural institution of slavery, actually exhibit subversive cultural educational practices of resistance. One example of this is the apostle Paul's letter to Philemon, where he sent back the runaway slave, Onesimus, to his master. While some interpret Paul's letter to make concessions with the institution of slavery, others see it as a radical proposal that would end slavery not only in Christian communities, but also in the society as a whole (Bakke, 2009). The Christian gospel exposes and upsets the society's discourse on slavery.

For these reasons, and others, we should not accept Rawls's narrow definition of a public forum. If houses of worship are public arenas, then practical theology requires a theology of public rhetoric or a public theology of rhetoric. Sermons, which function in a public forum to offer theological reflection on current social issues, are best suited to influence the discursive environment (in secular liberal democracies) when they model respect for the social agreement that tolerates public religious discourse. Today, the type of public agreement for the role of religious discourse is not what Aristotle had in mind when he wrote about the epideictic genre of ceremonial speech. $^{2}$ In our contemporary liberal democracies, we have come to recognize that the categories of political, ceremonial, and forensic rhetoric are not as distinct and tidy as they might have been understood in ancient Greece.

In this essay, we assert that the study of homiletics is able to recover that loss of public confidence in the religious speakers' ability to shepherd the public discourse, in secular liberal democracies. In what follows, we (1) describe the polarized nature of the American discursive community; (2) point out that a discourse ethic is latent in the communication rituals of this conversation community; (3) claim that Christian homiletic wisdom can and does accept and enhance the latent discourse ethic in secular liberal democracies by exercising a self-imposed restraint as an additional moral practice; (4) outline a pattern of homiletic movement that aligns liturgical witness to the logic of public religious discourse in the secular arena; and (5) lastly show that in this manner, Christian homiletics can reshape and transform the discourse environment for the sake of peace building in liberal democracies. By sketching a pattern of sermon movement that, given the social context of America, respects the logic operative in, and for, public theological discourse, pastoral care in sermon crafting must not neglect to become informed by academic discourse in other substantive matters like for example the social construction of race and ethnicity, if religious speakers are to positively influence public discourse skills. Religious public speakers can model (through sermons that are careful in handling facts and clarifying concepts)

\footnotetext{
2 Aristotle, The Rhetoric, Book 1 Chapter 3.
} 
best practices in public discourse. A claim is asserted that the way for religious orators to be fully present to a highly contested discourse environment is with a restrained engagement. Presence and engagement is the shepherding orator's gift of grace to the discursive community.

We have created our own agreement on how to talk about religious matters in the political arena. As we will show later in this essay, the discourse agreement in secular, liberal democracies is that public religious discourse is to be subjected to the following conditions: (1) that it values religious pluralism; (2) that it is committed to theological agnosticism and (3) that it surrenders to pragmatic tribunalism. Preachers can model public religious discourse that builds society via cultivating compassion and kindness (Heidt, 2010). In other words, sermons can metaphorically become the ingredients of salt and leaven in the service of discursive peacemaking. The divine call to become peacemakers comes with the charge to cultivate an atmosphere of civility. ${ }^{3}$

\section{Difficult (Polarized) Discourse: The Nature of the American Public Community}

In the current American context, public discourse practices are either heavily polarized or else they exploit the private lives of individuals in their vulnerable moments. Examples of this are seen and heard in political pundits of corporate media, talk radio, and/or the talk-shows and reality-TV confessionals. This polarization takes on its most intense moments when topics of religion and race are discussed. Take for example a quote from the December 2015 article in the L. A. Focus news paper,

If you look at the history of African-American movements—-from the 1960s when we talked about "Black Power," to the 1980s with Jesse Jackson and "I am somebody,” to Al Sharpton’s, “No Justice, No Peace,” you begin [to] get a sense that "Black Lives Matter' is more of a battle cry that resonates with a significant number of people. ${ }^{4}$

This article included a timeline with the pictures and date of death for 21 high-profile killings of African-American people beginning with Trayvon Martin, February 26 2012. Mass media has enormous tools to incite emotional energy for causes, movements, and battle cries. More examples of polarized and polluted public discourse are the less visible and somewhat muted academic debates among political theorists. Polarization can become pedagogical: through it, we can learn to struggle with the need to clarify our thinking. Polarization can also inflame violence and confuse our emotions.

We live in a liberal democracy. Liberal democratic governments, by their very nature, require a lot of their citizens. They produce highly discursive social cultures. In these discursive political fields, many voices vie to control the center. To the chagrin of some, the center appears to be occupied by secular liberals. In an effort to desire a healthy public forum, at present, social and political theorists disagree about how much discourse is too much. $^{5}$

On the one hand, there are those who represent the tradition of restraint. They emphasize liberty's role in restraining religious coercion. For them, freedom means freedom from coercion. A pioneering exemplar for this

\footnotetext{
3 I embrace James Calvin Davis’s definition of civility, “as the exercise of patience, integrity, humility, and mutual respect in civil conversation, even (or especially) with those with whom we disagree” distinct from the notions of civil discourse manifesting itself as passivity or relativism. See James Calvin Davis, In Defense of Civility: How Religion Can Unite America on Seven Moral Issues that Divide Us (Louisville, KY: Westminster John Knox Press, 2010), p.159.

${ }^{4}$ Unnamed staff writer, “Black Lives Matter: Movement or Battle Cry.” L. A. Focus volume XXI, Issue 12, December 2015.

${ }^{5}$ For this essay, I understand public in the sense of John Rawls; that is, "public in three ways: as the reason of citizens as such, it is the reason of the pubic; its subject is the good of the public and matters of fundamental justice; and its nature and content is public, being given by the ideals and principles expressed by society's conception of political justice, and conducted open to view on that basis” quoted in John Rawls, Political Liberalism (New York: Columbia University Press, 1993), p. 213.
} 
position is Thomas Paine. While the ink of his pen has dried, his words continue to inspire secular liberals. He wrote: "Of all the tyrannies that effect mankind, tyranny in religion is the worst; every other species of tyranny is limited to the world we live in; but this attempts to stride beyond the grave, and seeks to pursue us into eternity" (Paine, 1988). For secular liberals, these words define the agenda for people who seek to protect the social agreement regarding public religious discourse in the liberal democratic tradition. They believe our energies, as liberal societies, should be used in ways that protect the political community against a resurgence of religious tyranny. Religious arguments should not take center stage in the public arena.

For secularists, the threat of too much freedom of speech (particularly religious speech) add chaos to an already, overly crowded speech in the public arena. To add religious content to our public reasons runs the risk of opening Pandora's Box and creating social chaos. This kind of chaos, like competing paradigms during scientific revolutions, creates incommensurable communities because arguments in such an environment take on a necessarily circular form. ${ }^{6}$ This kind of discourse environment would be intolerable. A government that chooses to allow religiously inspired reasons to inform their public policy invites the potential for legal chaos. R. M. Veatch (2010) gives the example of state laws that allow people to invoke religious conscientious objection in order to define when the death of their loved one can be pronounced. He points out how some religions do not recognize brain death as death. The question naturally arises, whether or not we should legally accommodate religions that determine death by only recognizing "a criterion based on respiratory function" (Veatch, 2010, p. 137). Veatch asks the question, "How much individual choice in defining death can our society tolerate”? There is no doubt that religious discourse is a challenge for a pluralist society:

In a democratic, pluralistic culture, we have great insight into how to deal with religious, philosophical, and ethical issues about which there are strongly held views and unresolvable controversy. At the level of morality, we agree to tolerate diverse opinion, and we even let a person act on those opinions, at least until the effects on the lives of others become intolerable. This is the position we take regarding religious dissent. To the extent that the disagreement is a religious or quasi-religious disagreement, toleration of pluralism seems the appropriate course. It permits people with differences to live together in harmony. (Veatch, 2010, p. 139)

This quote from Veatch offers a charitable interpretation of the tradition of restraint. It recognizes that there are effects that can become intolerable and it is at that point where limits should be placed upon diverse opinions.

On the other hand, there are advocates who represent the expressive tradition. They emphasize liberty's role in positive terms. For these theorists, freedom means freedom to express one's self with regard to religious matters. ${ }^{7}$ The advocates of the expressive tradition find it ironic that secular liberals are so expressive in a debate where those same secularists argue for a discourse theory that would restrain the expressive voices of religion. There are those in this camp who fear that Thomas Paine has succeeded in setting up "the democratic policing of Christianity" (Haueerwas, 1994). They may even go as far as to claim that any democratic polity where sovereignty is with "the people" is the cause of a religious terror that replaces the divine power to govern

\footnotetext{
${ }^{6}$ Thomas Kuhn writes about arguments' circular form during competing paradigms: "Yet, whatever its force, the status of the circular argument is only that of persuasion. It cannot be made logically or even probabilistically compelling for those who refuse to step into the circle. The premises and values shared by the two parties to a debate over paradigms are not sufficiently extensive for that. As in political revolutions, so in paradigm choice - there is no standard higher than the assent of the relevant community." Thomas S. Kuhn, The Structure of Scientific Revolutions (Chicago: The University of Chicago Press, 1962), p. 94.

7 Jeffrey Stout writes that "The practical expression of social contract theory is, unsurprisingly, a program of social control, an attempt to enforce moral restraint on discursive exchange by counting only those who want to reason on the basis of a common set of fixed rules as reasonable.” See John Rawls, Political Liberalism (New York: Columbia University Press, 1993), p. 81.
} 
with the prerogative of the everyday person (Robbins, 2014). Cornel West, who writes about the black prophetic Christian tradition notes, "The separation of church and state is a pillar for any genuine democratic regime ... But religion will always play a fundamental role in the shaping of culture and politics in a democracy. All citizens must be free to speak out of their respective traditions...” (West, 2004). This desire to harness the energies of religion for concerted action, while at the same time restrain the religious energies of the liberal democratic tradition, is the oddity of the discursive environment in our culture. It is in this context that our cultural agreement serves the role of taming or housebreaking the religious energies of the citizenry. This can lead to an overreaching by democratic culture in the social control of religion. Robert Jensen offers some insight into the complexity of the challenge and its results when he writes:

Religion very evidently continues and will continue to be an option chosen by many. But wherever the self-understanding of pluralist society is in full power, either religion is accepted as a system of rhetoric not taken quite seriously, or the rhetoric is accepted seriously but the believer hides his true relation to society from himself, again emptying the rhetoric of point-e.g., Timothy Leary promoting withdrawal from the acquisitive society and eastern ascetism in a mansion donated by "a wealthy LSD enthusiast.” The new thing is therefore not that religion is no more an option, but that the religion that is an option is phony religion. At the moment, phony religion seems likely to be much more prominent in the mix of our spiritual pluralism that true religonlessness. (Jensen, 2010)

This polarization between the tradition of restraint and the expressive tradition with regard to religious speech in the public sphere makes it difficult for a person of faith (speaking out of their tradition) to know how to engage in the public discussions around religion and race. As a result, this polarized environment is rife with phony religion and this is broadcasted in many ways, including on the religious television networks.

\section{Complex Culture of Communication and a Latent Discourse Ethic}

At this point we are tempted to resist polarization as a pedagogical device or tool and to recognize that we often find ourselves in a discourse stalemate of failed attempts at persuasion. Neither side of the partisan camps (not the tradition of restraint nor the expressive tradition) has any better reason for giving up their ground to the other. Yet, for the peace of the human spirit and community, a less polarized discourse setting might be preferable. Most lean toward a more structured culture of communication. Promoting a public discourse community that encourages the continual, non-ending, cacophony of opposing moral visions engaged in ongoing debate seems impracticable (Connolly, 1999). Homiletic theory can guide a religious practitioner who operates in this kind of social space of persuasion.

Homiletics is a discipline that must now take on an interdisciplinary study of a culture's ritual of communication, so that in the training of preachers, homiletic wisdom will help students to become skilled in shepherding public discourse practices, especially during times of heated religious and racial rhetoric and debates. It is acknowledged that while the role of the religious speaker is a public role, the impact is limited, to some degree, to the preacher's influence upon his/her congregants. The religious speaker can reshape their ways of engaging in public discourse. Homiletic wisdom, modeled after a self-imposed restraint on public religious speech, moves preachers toward applying best practices in their sermons.

There are a least three important points to consider in secular liberal discursive contexts that inform the ritual of communication.

First, consider that liberal democracies exhibit a moral formation process of their own. They expect the members of the discursive community to participate in shaping the culture and by so doing these members 
develop their virtues as citizens. Preachers are part of that morally formative process. For this reason, religious speakers should protect this structure of communication. Mortimer Adler (1996) suggest what social disaster would befall our moral world should we give up on the liberal democratic project. The human efforts that socially protected the moral norm of justice, when constitutional governments were formed would erode. Because of constitutional governments, citizens ruled by law would now have some protections from the whims of a tyrant. Additionally, we socially protect the moral norm of liberty when liberal democratic governments formed. When those who must live by the rules are able to make the rules, they are protected from the tyranny of the elite. Finally, we socially protect the moral norm of equality when socialist democratic republics emerged (Adler, 1996). Thus liberal democracies reinforce the moral principles of justice, liberty, and equality. They form in their citizenry the moral virtues of a common good. Religious voices in public pulpits should honor these moral gains of liberal democracies, develop the virtue of restraint and participate in their own moral formation process.

Second, consider that liberal democratic societies formed as a response to a perceived threat from tyrannical regimes. Their response cultivated discursive communities that protect those who govern from those vices that fester when there is no accountability to the people. The triumph of the civil rights movement comes from the secularizing impulses of Christianity that confronted old religious dogmas through a peaceful civil disobedience. This in large part employed the tools of religious rhetoric that transposed Christian principles into language that was available in the public social space. This appears to be in jeopardy today. In some sense, our era attempts to reform society on top of the old grudges, which has resurfaced. The Southern Poverty Center cited in their intelligence report that at the start of the Obama presidency, there were 939 hate groups, which peaked to 1360 in 2012. This created a discourse façade. The same anger that divided the South seems interwoven in the fabric of American society. Nevertheless, as witnessed by the accountability strategies employed during the civil rights movement, we can say that we live in discursive communities that when at its best promotes virtuous public servants (Stouts, 2004).

Third, the history of religious traditions, like the Christian tradition, has dealt with the challenge of crafting their rhetoric in light of cultural rituals of communication that were unwelcoming. Leander Keck (1983) comments that

Long before moderns began discussing ideology, and "interest," and the sociology of knowledge, Paul saw the moral dimension of the knowledge of God...What Paul glimpses here is really the theological basis for public discourse that exposes the character of the culture's and the church's distortions of the reality called "God"'... [he goes on to say that] Rhetoric serves the preaching of the gospel...

Jeffrey Stout (2004, p. 82) proposes a way to balance the claims of the restraint tradition with those of the expressivist tradition. He calls for a "dialectic of normative constraint and novel performance..." where "The 'default-and-challenge-structure of entitlements' in a genuinely democratic ethical community is not to be understood in purely procedural terms. It is intimately connected with substantive commitments to mutual respect, equal voice, and the value of critical discussion” (Stout, 2004, p. 281). This dialectical model offers a creative way to map the discursive field. How do we deal with those who would use this kind of discursive space to exude antisocial behavior? How do we isolate those who would exploit and corrupt a permissive discourse environment? Practical theology can elucidate and name the latent "discourse ethic" (Browning, 1996) that is called for in the secular rituals of communication. And yet, whatever that latent discourse ethic may be, 
John Courtney Murray (1993, p. 151) is correct to note that: "From a practical point of view, society must have some way of protecting itself and its members against abuses committed in the name of the free exercise of religion.”

\section{Self-imposed Restraint and the Moral Dimension of Preaching}

It seems that Christian culture, which has given birth to secular nation states, has nurtured a discursive environment that now calls people of faith to reconsider the moral purposes of the rhetoricians who proclaim the faith. ${ }^{8}$ Secular liberals have been at the forefront of battles against the evils of tyranny, racial tyranny included. So, too, have many liberals of faith. There are those Christian theologians who argued that secularization is the inevitable consequence of biblical faith. Harvey Cox wrote,

...far from being something Christians should be against, secularization represents an authentic consequence of biblical faith. Rather than oppose it, the task of Christians should be to support and nourish it. ${ }^{9}$

Paul van Buren (1963, p. 199) added his secular interpretation of Christianity, and called for a "this-worldly" vision of the Christian gospel.

At this point, we can imagine some who might anticipate the direction that this argument is heading and offer push back against any project that silences the debate between the expressive and the restraint traditions. They might offer a series of rhetorical questions that must be considered. How can Christians, raised in cultures that impose a secular restraint on religious reasons, avoid acquiescing to the distorted visions of that culture? Isn't accepting the secular liberal's ritual of communication tantamount to the betrayal of the vocation to bear witness to the Lordship of Christ? Does it not make a difference, if ours is a culture that allows for "the democratic policing of Christianity" (Haueerwas, 1994)? What do we make of the effects of cultural conditioning on religious children whose spiritual leaders concede to the secular vision of public discourse?

If homiletics is to serve the discourse community, then the preachers must account for their moral purposes ${ }^{10}$ as they discover the latent moral vision embedded in the context of a secular liberal discourse community. A theology of rhetoric should cultivate the knowledge and art of public speaking. But if it neglects to address the moral purposes of the speaker, it has failed. For religious speakers, the moral purpose begins with "the moral integrity of God" (Leander, 1983, p. 136). For preachers in secular liberal democracies, the moral purpose is also informed by the commitments embedded in the political discourse of their societies. This moral purpose is captured in the form of life where the discourse takes place: human community. Secular liberal democratic discourse inevitably forms the moral characters of its participants. However, the preacher is faced with a dilemma in that the secular public is closed off to the preacher's rhetoric; as such, there is a need to ask what part they play in the formation process.

\footnotetext{
8 "Without the sacred space spearheaded by the church (or any other sacred gathering place), the secular world gathered about the church has little or no spirituality, morality, or ethics...In the secular world of essentially Christian communities...the aura of sacrality wafting above the core of secularity would cease to exist save the church and it personal oscillators, whose gift to the secular world is the spiritual substance of its natural law.” Jon Michael Spencer, Theological Music: Introduction to Theomusicology (New York: Greenwood Press, 1991), pp. 45-46.

${ }^{9}$ This quote begins much earlier where he writes, "the disenchantment of nature begins with the Creation; the desacralization of politics with the Exodus; and the deconsecration of values with the Sinai Covenant." Harvey Cox, The Secular City: Secularization and Urbanization in Theological Perspective (New York: The Macmillan Company, 1965), pp. 17-18.

${ }^{10}$ In his discourse on rhetoric, Aristotle wrote, "What makes a man a 'sophist' is not his faculty, but his moral purpose. In rhetoric, however, the term 'rhetorician' may describe either the speaker's knowledge of the art, or his moral purpose.” Aristotle, The Rhetoric, Book 1 Chapter 1, pp. 15-20.
} 
Because Christian preachers bear witness to Christ in a contested discourse space restraint is important. Practitioners speak to (and in) a minimally restrained discursive community. For persons familiar with the mid-twentieth century political and theological climate, the writings of Dietrich Bonhoeffer come to offer significant documents for reflection. In particular his July 16, 1944 letter to Eberhard Bethge, where he writes:

God as a working hypothesis in morals, politics, or science, has been surmounted and abolished; and the same thing has happened in philosophy and religion (Feuerbach!). For the sake of intellectual honesty, that working hypothesis should be dropped, or as far as possible eliminated...Here is the decisive difference between Christianity and all religions. Man's religiosity makes him look in his distress to the power of God in the world: God is the dues ex machina. The Bible directs man to God's powerlessness and suffering; only the suffering God can help. To that extent, we may say that the development towards the worlds coming of age outlined above, which has done away with a false conception of God, opens up a way of seeing the God of the Bible, who wins power and space in the world by his weakness. This will probably be the starting-point for our "secular interpretation". (Bonhoeffer, 1972, pp. 360-361)

Among the many things that this quote suggests, we want to highlight two. First, it implies that wherever the presence of "God" is found in our world today, it is a secular presence. Second, it suggests that wherever Christian witness hits upon success in the discourse space, it is won through weakness. Behind this quotation is the person of an imprisoned preacher-theologian who recognized the evils of the German Nazi regime and would not shy away from his duty to bear the Christian witness in the face of a racist ideology. How might religious public speakers exhibit presence and engagement in a discursive culture, which both invites and yet limits their discourse? Another way to reformulate this question is to ask, in a liberal secular society, how can religious rhetoric engage in public discourse when the secularizing forces have moved the theological rhetoric of the religious speaker away from the center of the discursive community?

Bonhoeffer's lectures on homiletics can be an educational tool to shape curriculum in the seminary classroom, rabbinical schools, Hindu ashrams, and Islamic madrasahs that would be helpful in training preachers and religious practitioners who desire to model for their members what this engagement might look like in the discourse community. Bonhoeffer, in his homiletic lectures to his students explained what this means about the nature of proclamation:

The proclaimed Christ is the real Christ. This proclamation is not a second incarnation. The offense caused by Jesus Christ is not his incarnation — that indeed is revelation—but his humiliation...In proclamation the risen and exalted one is thus present in his humiliation. (Bonhoeffer, 1991)

The role that the preacher must take in this discursive environment is the humble role. Many preachers are willing to let the secular person set the ground rules for the form and limit for the nature of their witness. They charitably afford persons in secular liberal democracies the right to design and structure the culture for communication.

So then, for the sake of argument, let's take for granted that we live in a cultural world that is stingy and unwelcoming to religious voices in the discourse space. Religious humility suggests that one can accept this ritual of communication, even in a culture that marginalizes among other venerated spirits (dare I say) the Lordship of Christ. Christians can humbly participate in this ritual of communication not simply for the sake of social peace, but primarily because their faith that the incarnate Christ presented in their proclamation is present in humiliation. Is not Christ's willingness to be proclaimed by broken, vulnerable, sinful humans a humiliating way to be present to the world? Homileticians need to reveal the "discourse ethic" that is latent in their own 
sacred ritual of communication. Embedded in the liturgical practices and in their sacred story, Christians center on the trial of Jesus (where the Negro Spiritual says, "he never said a mumbling word"). This account symbolizes the Christian public theologian's challenge to model their God-talk with a ritual of communication fashioned by self-imposed restraint on their public speech practices. In this way, they behave as authentic and respectable participants in an already prescribed socially ordered discourse.

Furthermore, they recognize that their presentation of Christ comes with Christ's willingness to once again take on the humiliating weakness of human speech. Bonhoeffer wrote:

The God who lets us live in the world without the working hypothesis of God is the God before whom we stand continually. Before God and with God we live without God. God lets himself be pushed out of the world and on to the cross. (1972, p. 360)

The vision and courage of Bonhoeffer, Cox, van Buren and, most of all, Jesus of Nazareth might help Christian preachers once again find their voice in a marginally welcoming public arena. In order to be true to their call, they must remind themselves that the way to be in this world is the way of God in Christ. That way is to be fully present with a restrained engagement. This is the humiliation of Christ. Presence and restrained engagement is the shepherding preacher's gift of grace to the discursive community.

\section{Aligning Sermon Form to the Logic of the Secular Public Domain}

To recap what we have said thus far: in a complex culture of communication, such as we experience in the polarized discursive American context, the preaching religious shepherd who models a way of witness that re-presents the incarnate Christ in his humiliation becomes a public pedagogue who shepherds the discourse practice by embodying the moral dimension of Christian public discourse, which demonstrates a form of self-imposed restraint. So it becomes evident that in liberal democracies sermons can either enhance public discourse or pervert it. It is also evident that preachers do not have the choice of making no impact at all. Sermons function to serve various goals. ${ }^{11}$ Sermons include goals that form the character of the whole person (Mitchell, 1990). Sermons form persons into a holistic faith as they, in part, shape the discourse culture. They often misfire in their rhetorical aims and intentions. ${ }^{12}$ This is sometimes the result of careless thinking. Worst still sermons sometimes exhibit and inspire antisocial behavior. When this happens, it is often the result of poor moral reflection and bad discourse habits. Religious rhetoric often feeds the cycle of polarized discursive community_but it has the potential to break and reverse that cycle. Sermons can become formative, reformative, and transformative speech events and documents for guiding social discourse.

Homiletics, as a dimension of religious education, can serve preachers in their pastoral care of the public discourse community. This is needed all the more in a context of religious and racially heated rhetoric. A homily's form can respect the rhetorical limits on modes of persuasion in secular liberal societies. The social agreement to contain the combative nature of religious discourse in the public arena assumes a logic that is circumscribed by commitments to: (1) value and explore our religious pluralism; (2) protect our theological agnosticism; and (3) employ our epistemological pragmatism. These categories might seem blunt and archaic

\footnotetext{
${ }^{11}$ Henry Grady Davis, Design for Preaching (Philadelphia: Fortress Press, 1958), pp. 98-162. See also the rhetorical purposes for sermons can be imaged as the preacher as herald, pastor, storyteller or witness in Thomas G. Long, The Witness of Preaching (Louisville, KY: Westminster/John Knox Press, 1989), p. 41. I want to add another image: the preacher as a confessor.

12 They demonstrate what J. L. Austin called "infelicities". see J. L. Austin, How to Do Things with Words (Cambridge, Mass: Harvard University Press, 1962), p. 18.
} 
compared to Jeffrey Stout's triumvirate of (1) mutual respect; (2) equal voice; and (3) the value of critical discussion (Stout, 2004). But we want to keep this trinary paradigm and offer an example of how sermons might honor these social commitments by sketching three moves, in a typical homily, that simulate and update what Timothy Cargal says is the core of Aristotle's tragic narrative: (1) the complication; (2) the crisis; and (3) the resolution (Cargal, 2007).

Both Stout's principle of mutual respect and what we call the principle of valuing religious pluralism describe the ethos of public discourse in secular liberal democracies today. It takes mutual respect to value religious pluralism. In the social climate of today's religiously plural societies, after the homilist completes the sermon introduction, the first move in the body of the homily should correspond to the complication in Aristotle's description of tragedy. This section of the homily's body would show how the cultural condition in a passage from the religious Scriptures is mimicked or reenacted in the real culture of today's hearers. In this way, the homilist taps into the real and latent anxiety of people who reside in religiously and racially plural communities. This provides the preacher with tools that highlight the complicated cultural conditions humans experience both in the text or behind the text and in our world today. In this move, the sermon values the plurovocity of both the biblical text and the lived context.

The second move corresponds to the crisis. Stout's principle of equal voice is somewhat related to what we call the principle of theological agnosticism. Having equal voice is an invitation for crisis by itself (in that falsity is never equal to truth), but it seems evident from the arrangement of the discursive environment that theological agnosticism is valued as the default faith in liberal democratic societies. Liberal democratic governments have their own implicit theological commitments. A public arrangement that values religious pluralism also entails a social consensus for theological agnosticism. Secular liberals recognize that, in principle, we cannot know whether God favors one religion over another or one social arrangement for many religions over another. Therefore, we must concede that for the common good, religious pluralism respects the human right to avowed atheism as well as devoted theism. Here is where preachers test their commitment to not behave in antisocial ways in the discourse community. In this second move, the sermon will tap into the agnostic sensibility of both the sacred text and the lived context. It is a part of human nature to be skeptical about many things, including the biological myth of race and claims to divine rights. Preachers need to find ways of acknowledging this skepticism and celebrating it. Here is where the homilist is able to gain credibility with reasonable skeptics in the congregation and to model for the members of the religious community and their guest how to discourse with similar skeptics who reside beyond the religious gathering.

The final move in the body of the sermon (that is the move before the sermon's conclusion) corresponds to the resolution. Stout's value of critical discussion relates to what we call the principle of pragmatic tribunalism or epistemological pragmatism. Given our inability to "know" how God would desire us to arrange the public square differently, we are left to make judgments about the common good, which in the final analysis are subject to pragmatic tests. Here, the sermon's resolution is humbly subjected to the market place of ideas. Its acceptance or rejection will be a test of the relevance of the sacred text to (and practicable application of it in) the lived context. Although Jeffrey Stout's definition of pragmatism is not uncontestable, it nevertheless encompasses many of the cognitive and emotive elements necessary for an adequate account. He writes:

Democracy is a culture, a tradition, in its own right. It has an ethical life of its own, which philosophers would do well to articulate. Pragmatism is best viewed as an attempt to bring the notions of democratic deliberation and tradition together in a single philosophical vision. To put the point aphoristically and paradoxically, pragmatism is democratic traditionalism. 
Less paradoxically, one could say that pragmatism is the philosophical space in which democratic rebellion against hierarchy combines with traditionalist love of virtue to form a new intellectual tradition that is indebted to both. (Stout, 2004, p. 13)

People in religiously plural social contexts need to cultivate spiritualities of uncertainty deeply rooted in religious fallibilism. Osmer (2008) correctly suggest that, "We must learn to live with uncertainty...We must also learn to live with the tension between different perspectives, including those of theology. These are spiritual challenges.” Graham (2002) argues that, especially for today, preachers must learn to desire and crave the pragmatic tribunal of the secular publics. When a message is rejected and ridiculed, it might become an opportunity for deep spiritual reflection on the part of the preacher. These common judges might happen to be a God given gift that reminds preachers of their fallible natures and of Christ's desire to be present in their proclamations as the humiliated Christ.

\section{Conclusion: Preaching for Peace Sake}

We conclude that the social agreement to tolerate public religious discourse implies an agreement to temper discourse participants. This tempering, it is hoped, will soften racial discourse as well. This is accomplished by our adhering to (and showing respect for) religious pluralism, theological agnosticism and pragmatic tribunalism. This essay attempts to invite preachers to model theological discourse that is covered by the full range of the challenging publics in secular liberal democratic societies. They can do this by a self-imposed restraint in their witness for the sake of the common good. Regardless of the mode of public theology, i.e., activist, civic, evangelistic, or sanctuary (Roozen, Mckinney, \& Carrol, 1984), the logic operative in the secular liberal democratic agreement, which admittedly is highly contested today, sets the challenge for an American Christian adherence to (and appropriation of) the apostle Paul's principle stated in 1 Corinthians 9: 19-23: to become all things to all people.

Paul strongly believed that the gospel was a liberating force to reshape and liberate society: transforming it into a place of peaceful discourse where the rights of all individuals in society are respected. Roger William's tried to model this in his discourse regarding the oppression of the native people of America. By aligning a pattern of homiletic movement to a social agreement that limits religious discourse, we can "bring the pulpit out of the shadows” (Craddock, 1987). In so doing, preachers can participate in the shepherding of public rhetorical skills.

What might be the result of another ad hoc experiment in our coffee shop, if this approach to homiletic training were implemented? We hold the conviction that one result should be that the customers in the coffee shop would relate to the pastor as a trustworthy secular guide. Thus in this context, the pastor is in the position to influence secular liberal democratic discourse communities, as it relates to God-talk. This shows that practicing a respectful public theology requires that practical theologians work within the social arrangement for public discourse. This calls for incarnational humility on the part of the public theologian and it guides her/his practice. It calls preachers to season their discourse environment and leaven their cultures with the gospel of peace.

\section{References}

Bakke, R. J. (2009). A theology as big as the city. Downers Grove, IL: InterVarsity Press. Bonhoeffer, D. (1972). Letters \& papers from prison. New York: Macmillan Publishing Co., Inc. 
Bonhoeffer, D. (1991). Worldly preaching: Lectures on homiletics. (C. E. Fant, Ed. \& Trans.). New York: The Crossroad Publishing Company.

Browning, D. S. (1996). A fundamental practical theology: Descriptive and strategic proposals. Minneapolis: Fortress Press.

Cargal, T. B. (2007). Hearing a film, seeing a sermon: Preaching and popular movies. Louisville, KY: Westminster John Knox Press.

Connolly, W. E. (1999). Why I am not a secularist. Minneapolis: University of Minnesota Press.

Craddock, F. B. (1987). As one without authority. Nashville, TN: Abingdon Press.

David, R., McKinney, W., \& Carroll, J. W. (1984). Varieties of religious presence, mission in public life. New York: The Pilgrim Press.

Derrick, A. Bell Jr. (1980). Brown V. Board of education and the interest convergence dilemma. In Critical race theory: The key writings that formed the movement (pp. 22-23).

Graham, E. L. (2002). Transforming practice: Pastoral theology in an age of uncertainty. Eugene, OR: Wipf and Stock Publishers.

Haueerwas, S. (1994). Dispatches from the front: Theological engagements with the secular. Durham: Duke University Press.

Heidt, M. R. (2010). Moral traditions: An introduction to world religious ethics. Winona, MN: Anselm Academic, Christian Brothers Publications.

Jensen, R. W. (2010). God after God: The God of the past and the God of the future as seen in the work of Karl Barth. Minneapolis: Fortress Press.

Keck, L. E. (1983). Toward a theology of rhetoric/preaching. In Don S. Browning (Ed.), Practical theology: The emerging field in theology, church, and world (p. 136). New York: Harper \& Row, Publishers.

M. van Buren, P. (1963). The secular meaning of the Gospel: Based on an analysis of its language. New York: The Macmillan Company.

Mitchell, H. H. (1990). Celebration \& experience in preaching. Nashville, TN: Abingdon Press.

Osmer, R. R. (2008). Practical theology: An introduction. Grand Rapids, MI: William B. Eerdmans Publishing Company.

Paine, T. (1988). The age of reason. New York: Citadel Press.

Rawls, J. (1993). Political liberalism. New York: Columbia University Press.

Robbins, J. W. (2014). The death of God and the politics of democracy. In D. J. Peterson and G. M. Zbaraschuk (Eds.), Resurrecting the death of God: The origins, influence, and return of radical theology (pp. 105-106). Albany, NY: SUNY Press.

Stout, J. (2004). Democracy and tradition. Princeton, NJ: Princeton University Press.

Stout, J. (2004). Democracy and tradition. Princeton, NJ: Princeton University Press.

Veatch, R. M. (2010). The conscience clause: How much individual choice in defining death can our society tolerate? In J. Pierce and G. Randels (Eds.), Contemporary bioethics: A reader with cases. New York: Oxford University Press.

West, C. (2004). Democracy matters: Winning the fight against imperialism. New York: The Penguin Press.

Wilder, C. S. (2014). Ebony and ivy: Race, slavery, and the troubled history of America's universities. Bloomsbury Publishing USA. 